\title{
REVIEW
}

\section{Congenital Zika Virus Infection Paradigm: What is in the Wardrobe? A Narrative Review}

\author{
Mariam M. Mirambo, a Lucas Matemba, ${ }^{b}$ Mtebe Majigo, ${ }^{c}$ Stephen E. Mshana ${ }^{a}$ \\ aDepartment of Microbiology and Immunology, Weill Bugando School of Medicine, Mwanza, Tanzania; bNational Institute for Medical Research, \\ Dar es Salaam, Tanzania; 'Department of Microbiology and Immunology, Muhimbili University of Health and Allied sciences, Dar es Salaam, Tanzania \\ Correspondence to Mariam M. Mirambo (mmmirambo@gmail.com)
}

\begin{abstract}
Background: Zika virus infection during pregnancy has been recently associated with congenital microcephaly and other severe neural tube defects. However, the magnitude of confirmed cases and the scope of these anomalies have not been extensively documented. This review focuses on the magnitude of laboratory-confirmed congenital Zika virus cases among probable cases and describing the patterns of congenital anomalies allegedly caused by the Zika virus, information which will inform further research in this area.

Methods: We conducted a literature search for English-language articles about congenital Zika virus infection using online electronic databases (PubMed/MEDLINE, POPLINE, Embase, Google Scholar, and Web of Knowledge). The search terms used were, "zika", "pregnancy", [year], "microcephaly", "infants", "children", "neonates", "foetuses", "neural tube defect", and "CNS manifestations" in different combinations. All articles reporting cases or case series between January 2015 and December 2016 were included. Data were entered into a Microsoft Excel database and analysed to obtain proportions of the confirmed cases and patterns of anomalies.

Results: A total of 24 articles (11 case series, 9 case reports, and 4 others) were found to be eligible and included in this review. These articles reported 919 cases, with or without microcephaly, presumed to have congenital Zika virus infection. Of these cases, $884(96.2 \%)$ had microcephaly. Of the 884 cases of microcephaly, $783(88.6 \%)$ were tested for Zika virus infection, and $216(27.6 \%$; $95 \%$ confidence interval, $24.5 \%$ to $30.8 \%)$ were confirmed to be Zika virus-positive. In addition to microcephaly, other common abnormalities reported - out of 442 cases investigated - were calcifications of brain tissue $(n=240$, $54.3 \%)$, ventriculomegaly $(n=93,20.8 \%)$, cerebellar hypoplasia $(n=52,11.7 \%)$, and ocular manifestations $(n=46,10.4 \%)$.

Conclusion: Based on the available literature, Zika virus infection during pregnancy might lead to a wide array of outcomes other than microcephaly. There is a need for more epidemiological studies in Zika-endemic areas, particularly in Africa, to ascertain the role of Zika virus in causing congenital neurological defects.
\end{abstract}

\section{INTRODUCTION}

Z ika virus (ZIKV) is anarthropod-borne virus transmitted mainly by mosquitoes of the genus Aedes. ${ }^{1,2}$ ZIKV was discovered in East Africa in 1947 from rhesus monkeys in Uganda's Zika forest, and human cases were confirmed a few years later in Tanzania and the Central African Republic. ${ }^{3}$ In recent years, the public health impact of ZIKV has been underscored by its association with Guillain-Barré syndrome and central nervous system congenital abnormalities. ${ }^{4-6}$ Between 2007 and 2016, several ZIKV outbreaks were reported in 52 countries and territories, including 40 countries that reported autochthonous transmission. By January 2016, locally transmitted cases from Puerto Rico and 19 countries or territories in the Americas had been reported to the
Pan Africa Health Organization. ${ }^{7}$ A total of 51,473 suspected cases of ZIKV had been reported in Brazil alone by March $2016 .^{8}$ In sub-Saharan Africa, outbreaks have been reported in Gabon, ${ }^{2}$ and recently, sporadic cases were reported in Angola. ${ }^{9}$

ZIKV is transmitted by mosquitoes, primarily of the genus Aedes. Aedes species, including Aedes aegypti, Aedes africanus, Aedes hensilli, and Aedes albopictus have been linked with ZIKV transmission. For example, A. hensilli mosquitoes were implicated in the 2007 Yap State outbreak in Micronesia. In Africa, the predominant Aedes species vector has not been definitively identified, although viral isolation studies suggest that $A$. albopictus was likely the vector connected to the 2007 ZIKV outbreak in Gabon., ${ }^{2,10-12}$ ZIKV infection is known to result from intrauterine or intrapartum transmission from a 
viraemic mother to her foetus or newborn (both resulting in congenital infection), sexual transmission, blood transfusions, and laboratory exposure. ${ }^{13-15}$ Although ZIKV RNA has been detected in breastmilk, transmission through breastfeeding has not been documented. ${ }^{16}$

ZIKV infection is asymptomatic in about $80 \%$ of cases ${ }^{17,18}$; when symptoms are present, they are usually mild and self-limiting. Commonly reported symptoms include rash, fever, arthralgia, myalgia, fatigue, headache, and conjunctivitis. These symptoms usually resolve within 2 weeks. Several clinical sequelae have been associated with ZIKV infection. ZIKV-associated congenital abnormalities have been observed in many countries outside of Africa. ${ }^{19-22}$ Following increasing reports on its association with congenital microcephaly in the Americas and Europe, ${ }^{23-25}$ the World Health Organization (WHO) declared ZIKV a public health emergency in early 2016.

The evaluation of clinical symptoms alone is unreliable in the diagnosis of ZIKV infection because of clinical overlap with other arboviruses. The diagnosis relies on laboratory testing; molecular amplification with real-time polymerase chain reaction (RT-PCR) assays on serum samples remains the most specific diagnostic approach and is the preferred testing method for ZIKV during the acute phase ( $<7$ days from symptom onset). Serologic testing for ZIKV is another option, although it is limited by potential cross-reactions with other flaviviruses, particularly dengue virus. ${ }^{19,20}$

There is no specific treatment or vaccine available for ZIKV infection. Management is based on supportive care, including rest, fluids, antipyretics, and analgesics. Other general measures focus on the prevention of mosquito bites include personal protection by wearing long pants, long sleeves, light-coloured clothing, and using insect repellents and bed nets. Pregnant women residing in countries that are not ZIKV endemic are advised against travel to affected countries. Testing should be offered to all pregnant women who have travelled to areas with ongoing Zika virus transmission.

Previous and ongoing studies have investigated the apparent causal link between ZIKV infection and congenital anomalies and sequelae, with the majority of reported cases falling under the "probable" category because of a lack of laboratory evidence to support the hypothesised causality. This obfuscates the magnitude of the problem. There are limited data to help quantify confirmed cases and the associated pattern of anomalies. It is important to generate, analyse, and compile such data because most anomalies allegedly caused by congenital ZIKV infection can also be caused by other pathogens, such as rubella virus, cytomegalovirus, Toxoplasma gondii, parvovirus B19, Treponema pallidum, and herpes simplex virus type 2 , for example. ${ }^{21}$ This review aimed at documenting the magnitude of the reported laboratory-confirmed congenital ZIKV cases and the patterns of congenital anomalies potentially caused by congenital ZIKV infection. This information may be useful for ascertaining the knowl- edge gap to be filled by future research, especially as there are still more questions than answers regarding congenital ZIKV infection.

\section{METHODS}

\section{Search Strategy}

We conducted a literature search for English-language articles about ZIKV infection published between 2015 and 2016. During this period, WHO and different organisations, such as the US Centers for Disease Control and Prevention (CDC) laid down clear guidelines for ZIKV diagnosis. The search terms used were, "zika", "pregnancy", [year], "microcephaly", "infants", "children", "neonates", "foetuses", "neural tube defect", and "CNS manifestations" in different combinations. After each search, the links displayed in the abstracts were followed to yield more results. The bibliographies of the retrieved articles were carefully reviewed to yield more articles.

\section{Information Sources}

Information was searched from the online databases PubMed/MEDLINE, POPLINE, Google Scholar, Embase, and Web of Knowledge between 1 July and 31 December 2016. Only studies published in scientific journals were included. We used a checklist to extract the relevant information from each included article, and no authors were contacted for additional information.

\section{Eligibility Criteria and Study Selection}

As this review aimed to quantify laboratory-confirmed cases and delineate the pattern of anomalies, we included case reports, case series, and cross-sectional studies with descriptions of cases published in English between 2015 and 2016. All search results reporting on cases were included in this review. Articles were screened for the completeness of data; articles reporting ZIKV infection in the general population, news and epidemiological alerts, review articles, and articles with evidence of data repetition were excluded. All studies were assessed for methodological quality using a checklist. ${ }^{26}$

A total of 2,134 articles and abstracts were obtained; 1,761 were excluded because of duplication, leaving 373 abstracts and articles to be analysed for eligibility, of which 320 were excluded. Finally, 53 full articles were critically reviewed. Only 24 articles ( 11 case series, 9 case reports, 2 cross-sectional studies, 1 case-control study, and 1 cohort study) were found to be eligible and included in this review (Figure 1).

\section{Data Collection Process}

Two independent reviewers performed data extraction using a checklist with the headings Author, Study Period, Year of Publication, Study Area/Country, Sample Size, Study Design, Clinical Presentation, Imaging Results, Cases Tested, Diagnostic Technique, and Mother Symptoms, where applicable. 


\section{FIGURE 1. PRISMA Diagram Outlining the Article Selection Process}

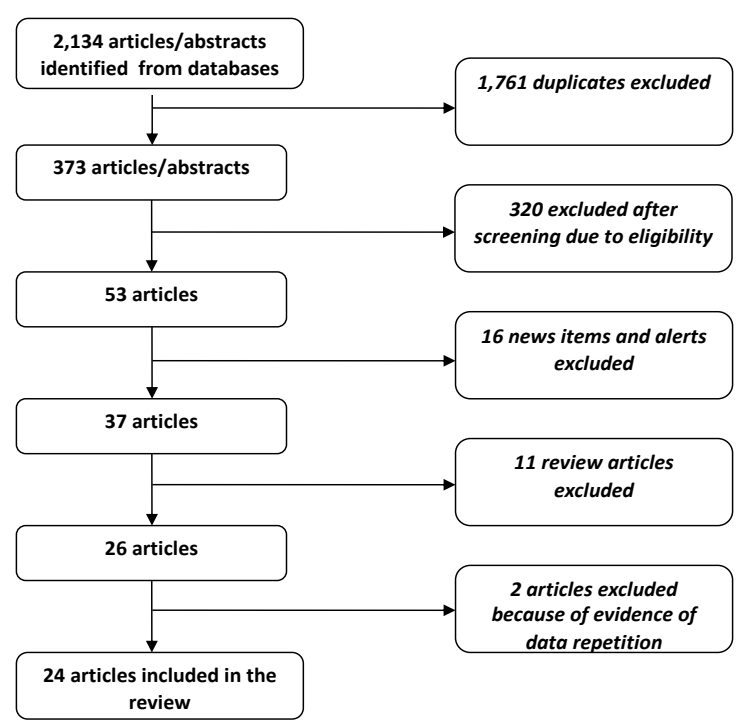

All studies described cases, and laboratory confirmation was done using recommended techniques, such as RT-PCR and IgM immunoassays. ${ }^{19,20}$

\section{Summary Measures}

Unweighted analysis was carried out, whereby the outcomes of individual studies were counted to quantify the proportions of cases with microcephaly and laboratory-confirmed cases, as well as describe patterns of congenital anomalies. We calculated $95 \%$ confidence intervals using 2 -sample proportion tests.

\section{Ethical Approval}

Ethical approval to conduct and publish this review was obtained from the Joint Catholic University of Health and Allied Sciences/Bugando Medical Centre (CUHAS/BMC) Ethical Review Committee (CREC/043/2014/2015/2016).

\section{RESULTS}

\section{Study Characteristics}

Of the 24 articles included in the final analysis, $20(83.3 \%)$ were case series or case reports. Most of the data were collected between February 2015 and June 2016. The majority $(n=21,87.5 \%)$ of the studies were conducted in South America (Table). Seventeen (70.8\%) of the articles reported on laboratory results associated with ZIKV infection. Five articles reported PCR as the sole laboratory technique, while 13 articles reported the use of IgM immunoassays along with PCR assays. All articles reported on the presence or absence of mi- crocephaly. Nineteen $(79.2 \%)$ of the studies investigated other causes of congenital anomalies, such as rubella, T. gondii, cytomegalovirus, parvovirus B19, T. pallidum, herpes simplex type 2, and HIV. Various combinations of ultrasound, computed tomography, magnetic resonance imaging, and plain $\mathrm{x}$-rays were employed to establish imaging findings. Seventeen $(68 \%)$ articles reported on maternal clinical signs and symptoms during pregnancy.

\section{Synthesis of Results}

A total of 919 cases with central nervous system manifestations with or without laboratory confirmation of ZIKV infection were reported in the 24 articles. The majority of these studies were from Brazil (Table). There were 884 (96.2\%) cases of microcephaly. Maternal clinical data were available for 309 mothers whose babies had microcephaly. Among these 309 women, the common signs and symptoms were rash $(n=189,61.8)$, arthralgia or myalgia $(n=65,21 \%)$, and fever $(n=62,20.1 \%)$. The details of the analysed articles are summarised in the Table.

\section{Diagnosis of ZIKV Infection}

Out of 884 cases of microcephaly, 783 (88.6\%) were tested for ZIKV infection. Of the 783 tested samples, 216 (27.6\%; 95\% CI, $24.5 \%$ to $30.8 \%$ ) were confirmed to be positive for ZIKV infection. Of 35 cases without microcephaly, 11 (31.4\%) tested positive for ZIKV infection. Of the 227 confirmed cases, most $(n=153,67.1 \%)$ were confirmed by IgM enzyme immunoassay (EIA). The commonest sample type used for laboratory confirmation of ZIKV infection was blood $(n=761$ of 783 , 
FIGURE 2. Imaging Findings for 442 Microcephaly Cases

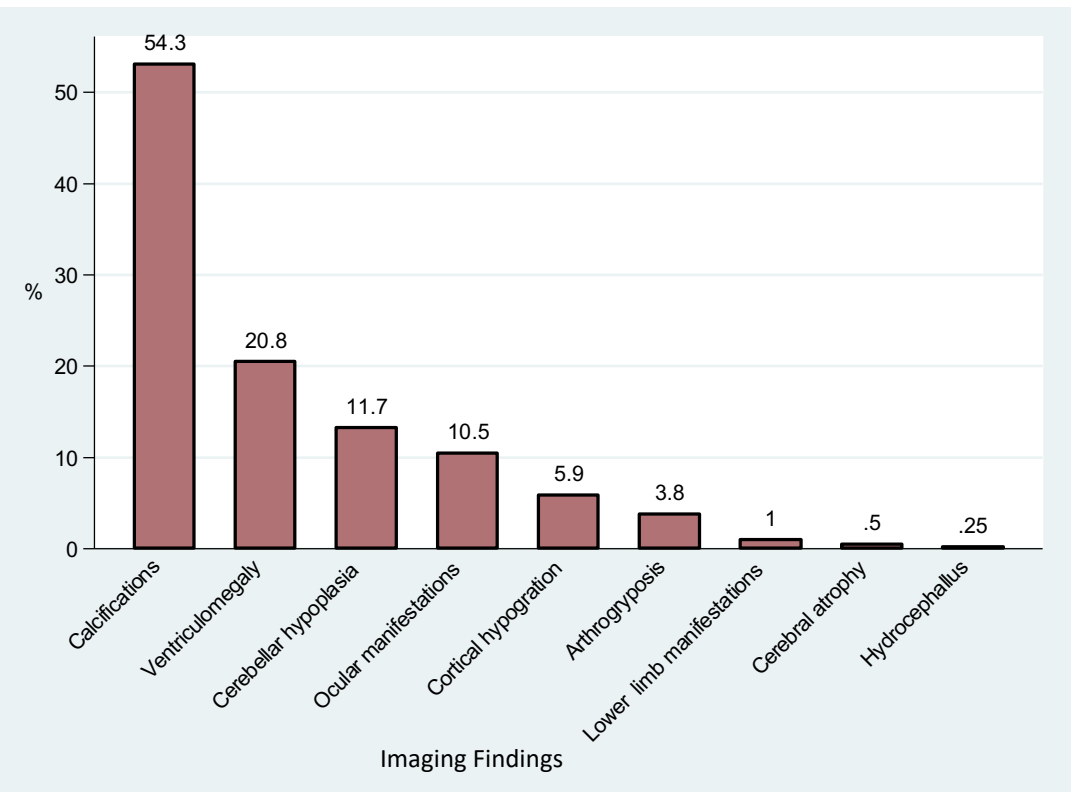

$97.2 \%)$, followed by cerebrospinal fluid in $86(11 \%)$ of 783 cases. Both amniotic fluid and tissue samples were used in 14 cases, urine was used in 8 cases, and amniotic fluid only was used in 8 cases. Four cases relied on only tissue samples for diagnosis. Histopathological findings using haematoxylin and eosin staining and immunohistochemistry were investigated for 6 cases, all of which had calcifications, with macrophages and perivascular infiltrates observed in 1 case.

\section{Imaging Findings}

Of the 883 cases with microcephaly, imaging results were available for $442(50.1 \%)$. The commonest finding was calcifications $(n=240,54.3 \%)$, followed by ventriculomegaly $(n=92$, $20.8 \%$ ), cerebellar hypoplasia ( $n=52,11.7 \%)$, and ocular manifestations - including chorioretinal scarring, macular pigmentation, fovea and reflex loss, microphthalmia, intraocular calcifications, cataracts, and microphthalmia $(n=46,10.4 \%)$. Other findings included cortical hypogyration $(n=23,5.2 \%)$, arthrogryposis $(n=15,3.4 \%)$, lower limb manifestations $(n=6$, $1.4 \%)$, cerebral atrophy $(n=2,0.5 \%)$, and hydrocephalus $(n=1,0.25 \%)$. The details of the findings are summarised in Figure 2. Adverse pregnancy outcomes observed were miscarriages $(n=7)$, intrauterine growth retardation $(n=4)$, hydrops foetalis $(n=1)$, and stillbirths $(n=2)$.

\section{DISCUSSION}

This report summarises the magnitude of confirmed congenital ZIKV infection and the scope of anomalies that might be caused by ZIKV. An important finding is the magnitude of the confirmed cases, which reflects progress in investigating the link of causality. Only a quarter of "probable cases" were laboratory confirmed as cases of ZIKV infection. The small proportion of confirmed cases could be due to the unknown course of the disease, the time taken for viral markers to disappear after congenital infections, and the sensitivity of the available assays. There is a need for a coordinated effort to develop inexpensive, specific, and sensitive tests to diagnose ZIKV infection. To date, only a few assays have been approved and recommended by WHO. ${ }^{22}$

Another important observation is that three-quarters of ZIKV studies in this review ruled out other causes of congenital anomalies - such as rubella virus, T. gondii, cytomegalovirus, parvovirus B 19, T. pallidum, herpes simplex type 2, and HIV - which is important for providing more robust evidence for the association between ZIKV and congenital anomalies. It is crucial to screen for other causes of congenital anomalies during the diagnosis of potential ZIKV cases, particularly in developing countries where these infections are most prevalent. . $^{27-36}$

The majority of the articles in this review included well-studied cases highlighting the widely varying patterns of congenital ZIKV presentation. As has been done for the 
TABLE. Summary of the Articles Included in the Review

\begin{tabular}{|c|c|c|c|c|c|c|}
\hline $\begin{array}{l}\text { Study } \\
\text { Number }\end{array}$ & Study Design ${ }^{\text {ref }}$ & Study Location & $\begin{array}{c}\text { Sample Size } \\
\text { N }\end{array}$ & $\begin{array}{c}\text { CNS Manifestations } \\
\mathbf{n}\end{array}$ & $\begin{array}{c}\text { Microcephaly } \\
\mathrm{n}\end{array}$ & $\begin{array}{c}\text { Lab results } \\
n\end{array}$ \\
\hline 1 & Case report ${ }^{23}$ & $\begin{array}{c}\text { Washington DC, } \\
\text { USA }\end{array}$ & 1 & 1 & 0 & ND \\
\hline 2 & Case report $^{24}$ & Paraiba, Brazil & 2 & 2 & 2 & 2 \\
\hline 3 & Cohort study ${ }^{25}$ & $\begin{array}{c}\text { Rio de Janeiro, } \\
\text { Brazil }\end{array}$ & 88 & 12 & 4 & ND \\
\hline 4 & Case series $^{27}$ & Pernambuco, Brazil & 7 & 7 & 7 & 2 \\
\hline 5 & Case series $^{43,60}$ & Eight states, Brazil & 35 & 35 & 35 & ND \\
\hline 6 & Case report ${ }^{44}$ & Sao Paulo, Brazil & 1 & 1 & 0 & ND \\
\hline 7 & Case series $^{16}$ & French Polynesia & 3 & 2 & 2 & ND \\
\hline 8 & Case report ${ }^{10}$ & Paraiba, Brazil & 2 & 2 & 2 & 2 \\
\hline 9 & Case report ${ }^{46}$ & Slovenia, Europe & 1 & 1 & 1 & 1 \\
\hline 10 & Case-control $^{47}$ & Recife, Brazil & 32 & 32 & 32 & 13 \\
\hline 11 & Cross-sectional $^{48}$ & Brazil & 602 & 602 & 602 & 76 \\
\hline 12 & Case series $^{49}$ & Paraiba, Brazil & 23 & 23 & 23 & 7 \\
\hline 13 & Case report ${ }^{50}$ & Salvador, Brazil & 1 & 1 & 1 & 1 \\
\hline 14 & Case report ${ }^{51}$ & Pernambuco, Brazil & 70 & 70 & 70 & 70 \\
\hline 15 & Case series $^{52}$ & Brazil & $5 a$ & 5 & 2 & 2 \\
\hline 16 & Case series $^{53}$ & French Polynesia & 19 & 19 & 8 & 4 \\
\hline 17 & Case series $^{54}$ & Salvador, Brazil & 29 & 29 & 29 & ND \\
\hline 18 & Case report ${ }^{55}$ & Brazil & 1 & 1 & 1 & 1 \\
\hline 19 & Case series $^{56}$ & Paraiba, Brazil & 11 & 11 & 11 & 6 \\
\hline 20 & Case report ${ }^{58}$ & Spain & 1 & 1 & 0 & 1 \\
\hline 21 & Cross-sectional $^{59}$ & USA & 26 & 26 & 18 & 26 \\
\hline 22 & Case series $^{60}$ & Brazil & 19 & 19 & 19 & 5 \\
\hline 23 & Case series $^{13}$ & Brazil & 3 & 3 & 3 & 2 \\
\hline \multirow[t]{2}{*}{24} & Case series $^{61}$ & Brazil & 13 & 13 & 11 & 13 \\
\hline & & Total & 994 & 919 & 884 & \\
\hline
\end{tabular}

The diagnosis included 3 tissues samples

Abbreviation: ND, not determined 
congenital rubella syndrome, ${ }^{37}$ there is a need to establish a pathognomonic features list and case definitions for congenital ZIKV infection.

Regarding laboratory diagnosis of ZIKV infection, half $(\mathrm{n}=12)$ of the included articles confirmed ZIKV infection using EIAs and PCR assays. The diagnosis of ZIKV infection similarly to other closely related viruses, such as the chikungunya, dengue, and yellow fever viruses - has become challenging due to cross-reactivity, which hinders the specificity of the available diagnostic techniques. ${ }^{38,39}$ Sensitive and specific assays to confirm ZIKV infection are in high demand at this time of increasing anxiety related to ZIKV and its associated sequelae in both developed and developing countries. Given that most congenital infections are associated with similar maternal clinical presentations during pregnancy and given the high incidence of congenital anomalies with unidentified causes being reported in developing countries, ${ }^{40} \mathrm{re}-$ liable and affordable diagnostic techniques for the screening these infections at the point of care are paramount.

This review highlighted the common clinical manifestations of congenital ZIKV infections. Cerebral calcifications were the most common imaging finding, followed by ventriculomegaly, cerebellar hypoplasia, and ocular manifestations. This suggests that congenital ZIKV infection causes a wide array of congenital anomalies, aside from microcephaly, which calls for thorough clinical examinations and investigations of all neonates with congenital anomalies. Even though ZIKV is known to be neurotropic, ${ }^{41,42}$ manifestations involving other organ systems are possible, and this must be remembered when considering ZIKV's role in causing congenital anomalies, particularly in endemic developing countries where the majority of congenital anomalies have no identified causes. Furthermore, apart from the congenital abnormalities mentioned herein, ZIKV might also cause a diverse range of adverse pregnancy outcomes, such as miscarriages, stillbirths, and intrauterine growth retardation.

In general, this review provides an overview of the current situation regarding confirmed congenital ZIKV infection along with the scope of outcomes, which may be useful for future research and for designing control strategies. Nevertheless, we must mention several drawbacks. For example, some of the articles did not clearly indicate how many microcephalic newborns underwent imaging studies. This might lead to an inaccurate understanding of the patterns of imaging findings. Similarly, most of the articles did not report maternal clinical features during pregnancy, information that could lead clinicians to have a high index of suspicion for ZIKV infection when appropriate. Another limitation was that some studies did not rule out other causes of congenital anomalies.

\section{CONCLUSION}

Congenital ZIKV infections might be associated with a wider spectrum of anomalies aside from microcephaly. This necessitates thorough clinical examination and investigation whenever a congenital infection is suspected. Diagnostic assays to confirm ZIKV infection are urgently needed, especially in areas where ZIKV is endemic. There is a need to develop a standardised format for reporting results regarding congenital ZIKV infections to allow pooling of data for public use. Additionally, we recommend further research on ZIKV strains in relation to the pattern of congenital anomalies.

Acknowledgements: The authors would like to acknowledge the support provided by Ms Caroline Minja, Dr Najma Awadh, Ms Ruth Rakiru, and the CUHAS Library staff. This study was supported by a research grant from CUHAS to MMM.

\section{REFERENCES}

1. Baraka $V$, Kweka EJ. The threat of Zika virus in sub-Saharan Africa - the need to remain vigilant. Front Public Health. 2016;4:110. CrossRef. Medline

2. Grard G, Caron M, Mombo IM, et al. Zika virus in Gabon (Central Africa) 2007: a new threat from Aedes albopictus? PLoS Negl Trop Dis. 2014;8(2): e2681. CrossRef. Medline

3. Berthet $N$, Nakouné $E$, Kamgang B, et al. Molecular characterization of three Zika flaviviruses obtained from sylvatic mosquitoes in the Central African Republic. Vector Borne Zoonotic Dis. 2014;14(12):862-865. CrossRef. Medline

4. Cao-Lormeau VM, Blake A, Mons S, et al. Guillain-Barré syndrome outbreak associated with Zika virus infection in French Polynesia: a case-control study. Lancet. 2016; 387(10027): 1531-1539. CrossRef. Medline

5. Oehler E, Watrin L, Larre $P$, et al. Zika virus infection complicated by Guillain-Barré syndrome - case report, French Polynesia, December 2013. Euro Surveill. 2014;19(9): 20720. CrossRef. Medline

6. Zanluca C, de Melo VCA, Mosimann ALP, dos Santos GIV, dos Santos CND, Luz K. First report of autochthonous transmission of Zika virus in Brazil. Mem Instituto Oswaldo Cruz. 2015;110(4):569-572. CrossRef. Medline

7. Hennessey M, Fischer M, Staples JE. Zika virus spreads to new areas - region of the Americas, May 2015-January 2016. MMWR Morb Mortal Wkly Rep. 2016;65(3):55-58. CrossRef. Medline

8. World Health Organization (WHO). Situation Report: Zika Virus, Microcephaly, Guillain-Barré Syndrome. Geneva: WHO; 2016. https://apps.who.int/iris/ handle/10665/250049. Accessed 28 February 2019.

9. Sassetti M, Zé-Zé L, Franco J, et al. First case of confirmed congenital Zika syndrome in continental Africa. Trans R Soc Trop Med Hyg. 2018;1 12(10):458 462. CrossRef. Medline

10. Dick GW, Kitchen SF, Haddow AJ. Zika virus. I. Isolations and serological specificity. Trans R Soc Trop Med Hyg. 1952;46(5):509-520. Medline

11. Marchette N, Garcia R, Rudnick A. Isolation of Zika virus from Aedes aegypti mosquitoes in Malaysia. Am J Trop Med Hyg. 1969;18(3):41 1-415. CrossRef. Medline

12. Hayes EB. Zika virus outside Africa. Emerg Infect Dis. 2009;15(9):1347-1350. CrossRef. Medline

13. Oliveira Melo AS, Malinger G, Ximenes R, Szejnfeld PO, Alves Sampaio $S$, Bispo de Filippis AM. Zika virus intrauterine infection causes fetal brain abnormality and microcephaly: tip of the iceberg? Ultrasound Obstet Gynecol. 2016;47(1): 6-7. CrossRef. Medline

14. Musso D, Roche C, Robin E, Nhan T, Teissier A, Cao-Lormeau VM. Potentia sexual transmission of Zika virus. Emerg Infect Dis. 2015;21(2):359-361. CrossRef. Medline

15. Musso D, Nhan $T$, Robin $E$, et al. Potential for Zika virus transmission through blood transfusion demonstrated during an outbreak in French Polynesia, November 2013 to February 2014. Euro Surveill. 2014;19(14):20761. CrossRef. Medline

16. Besnard M, Lastère $S$, Teissier A, Cao-Lormeau V, Musso D. Evidence of perinatal transmission of Zika virus, French Polynesia, December 2013 and February 2014. Euro Surveill. 2014;19(13):20751. CrossRef. Medline 
17. Duffy MR, Chen TH, Hancock WT, et al. Zika virus outbreak on Yap Island, Federated States of Micronesia. N Engl J Med. 2009;360(24):2536-2543. CrossRef. Medline

18. loos S, Mallet HP, Leparc Goffart I, Gauthier V, Cardoso T, Herida M. Current Zika virus epidemiology and recent epidemics. Med Mal Infect. 2014;44(7):302-307. CrossRef. Medline

19. Landry ML, St George K. Laboratory diagnosis of Zika virus infection. Arch Pathol Lab Med. 2016;141(1):60-67. CrossRef. Medline

20. Waggoner JJ, Pinsky BA. Zika virus: diagnostics for an emerging pandemic threat. J Clin Microbiol. 2016:54(4):860-867. CrossRef. Medline

21. Stegmann BJ, Carey JC. TORCH infections. Toxoplasmosis, other (syphilis, varicella-zoster, parvovirus B19), rubella, cytomegalovirus (CMV), and herpes infections. Curr Womens Health Rep. 2002;2(4):253-258. Medline

22. World Health Organization (WHO). Emergency Use Assessment and Listing (EUAL) Update. Update on Submission of Applications to the WHO EUAL for Zika Virus IVDs Summary of Activities: 01 November 2016. Geneva: WHO; 2016. https://www.who.int/diagnostics_laboratory/eual-zika-virus/161101 weekly_update.pdf. Accessed 28 February 2019.

23. Driggers RW, Ho CY, Korhonen EM, et al. Zika virus infection with pro longed maternal viremia and fetal brain abnormalities. N Engl J Med. 2016:374(22):2142-2151. CrossRef. Medline

24. Calvet G, Aguiar RS, Melo ASO, et al. Detection and sequencing of Zika virus from amniotic fluid of fetuses with microcephaly in Brazil: a case study. Lancet Infect Dis. 2016;16(6):653-660. CrossRef. Medline

25. Brasil P, Pereira JP Jr, Moreira ME, et al. Zika virus infection in pregnant women in Rio de Janeiro. New Engl J Med. 2016;375(24):2321-2334. CrossRef. Medline

26. Scottish Intercollegiate Guidelines Network (SIGN). Critical appraisal notes and checklists. SIGN Website. https://www.sign.ac.uk/checklists-and-notes.html. Accessed 10 March 2019

27. van der Linden V, Filho EL, Lins OG, et al. Congenital Zika syndrome with arthrogryposis: retrospective case series study. BMJ. 2016;354:i3899. CrossRef. Medline

28. Mirambo MM, Chibwe E, Mushi MF, Majigo M, Mshana SE. Cytomegalovirus, parvovirus B19 and rubella co-infection among pregnant women attending antenatal clinics in Mwanza City: the need to be considered in Tanzanian antenatal care package. Epidemiol (Sunnyvale). 2016;6:230. CrossRef

29. Mirambo MM, Aboud S, Mushi MF, et al. Serological evidence of acute rubella infection among under-fives in Mwanza: a threat to increasing rates of congenital rubella syndrome in Tanzania. Ital J Pediatr. 2016;42(1):54. CrossRef. Medline

30. Mwambe B, Mirambo MM, Mshana SE, et al. Sero-positivity rate of rubella and associated factors among pregnant women attending antenatal care in Mwanza, Tanzania. BMC Pregnancy Childbirth. 2014;14:95. CrossRef. Medline

31. Nessa A, Islam MN, Tabassum S, Munshi SU, Ahmed M, Karim R. Seroprevalence of rubella among urban and rural Bangladeshi women emphasises the need for rubella vaccination of pre-pubertal girls. Indian J Med Microbiol. 2008;26(1):94-95. CrossRef. Medline

32. Onyenekwe CC, Kehinde-Agbeyangi TA, Ofor US, Arinola OG. Prevalence of rubella-lgG antibody in women of childbearing age in Lagos, Nigeria. West Afr J Med. 1999;19(1):23-26. Medline

33. Oyinloye SO, Amama CA, Daniel R, Ajayi BB, Lawan MA. Seroprevalence survey of rubella antibodies among pregnant women in Maiduguri, Borno State, Nigeria. Afr J Clin Exp Microbiol. 2014;15(3):151-157. CrossRef

34. Rashid S, Kilewo C, Aboud S. Seroprevalence of hepatitis B virus infection among antenatal clinic attendees at a tertiary hospital in Dar es Salaam, Tanzania. Tanzan J Health Res. 2014;16(1):9-15. CrossRef. Medline

35. Rodier MH, Berthonneau J, Bourgoin A, et al. Seroprevalences of toxoplasma, malaria, rubella, cytomegalovirus, HIV, and treponemal infections among pregnant women in Cotonou, Republic of Benin. Acta Trop. 1995;59(4):271-277. CrossRef. Medline

36. Yadav RK, Maity S, Saha S. A review on TORCH: groups of congenital infection during pregnancy. J Sci Innov Res. 2014;3(2):258-264.
37. World Health Organization (WHO). Rubella vaccines: WHO position paper. Wkly Epidemiol Rec. $2011 ; 86(29): 301-316$. Medline

38. Koraka P, Zeller H, Niedrig M, Osterhaus AD, Groen J. Reactivity of serum samples from patients with a flavivirus infection measured by immunofluorescence assay and ELISA. Microbes Infect. 2002;4(12):1209-1215. CrossRef. Medline

39. Allwinn R, Doerr H, Emmerich P, Schmitz H, Preiser W. Cross-reactivity in flavivirus serology: new implications of an old finding? Med Microbiol Immunol. 2002;190(4): 199-202. Medline

40. Mashuda F, Zuechner A, Chalya P, Kidenya BR, Manyama M. Pattern and factors associated with congenital anomalies among young infants admitted at Bugando Medical Centre, Mwanza, Tanzania. BMC Res Notes. 2014;7:195. CrossRef. Medline

41. Carod-Artal FJ. Epidemiology and neurological complications of infection by the Zika virus: a new emerging neurotropic virus. Rev Neurol. 2016; 62(7):317-328. CrossRef. Medline

42. Ricketson R, Lyons-Weiler J. Zika virus induced neurotropic brain injury: lessons for the study of disease etiology and vaccine development against pathogens. WebmedCentral Virol. 2016;(7):WMC005082.

43. Schuler-Faccini L, Ribeiro EM, Feitosa IM, et al. Possible association between Zika virus infection and microcephaly - Brazil, 2015. MMWR Morb Mortal Wkly Rep. 2016;65(3):59-62. CrossRef. Medline

44. Ventura CV, Maia M, Dias N, Ventura LO, Belfort R Jr. Zika: neurological and ocular findings in infant without microcephaly. Lancet. 2016;387(10037):2502. CrossRef. Medline

45. Ventura CV, Maia M, Ventura BV, et al. Ophthalmological findings in infants with microcephaly and presumable intra-uterus Zika virus infection. Arq Bras Oftalmol. 2016;79(1): 1-3. CrossRef. Medline

46. Mlakar J, Korva M, Tul N, et al. Zika virus associated with microcephaly. $N$ Engl J Med. 2016; 374(10):951-958. CrossRef. Medline

47. de Araújo TVB, Rodrigues LC, de Alencar Ximenes RA, et al. Association between Zika virus infection and microcephaly in Brazil, January to May, 2016 preliminary report of a case-control study. Lancet Infect Dis. 2016;16(12):1356 1363. CrossRef. Medline

48. Rubin EJ, Greene MF, Baden LR. Zika virus and microcephaly. New Engl J Med. 2016;374(10):984-985. CrossRef. Medline

49. França GV, Schuler-Faccini L, Oliveira WK, et al. Congenital Zika virus syndrome in Brazil: a case series of the first 1501 livebirths with complete inves tigation. Lancet. 2016;388(10047):891-897. CrossRef. Medline

50. de Oliveira Melo AS, Santana Aguiar R, Ramos Amorim MM, et al. Congenital Zika virus infection: beyond neonatal microcephaly. JAMA Neurol. 2016;73(12):1407-1416. CrossRef. Medline

51. Sarno M, Sacramento GA, Khouri R, et al. Zika virus infection and stillbirths: a case of hydrops fetalis, hydranencephaly and fetal demise. PLoS Negl Trop Dis. 2016;10(2):e0004517. CrossRef. Medline

52. Leal MC, Muniz LF, Ferreira TS, et al. Hearing loss in infants with microcephaly and evidence of congenital Zika virus infection - Brazil, November 2015-May 2016. MMWR Morb Mortal Wkly Rep. 2016;65(34):917-919. CrossRef. Medline

53. Martines RB, Bhatnagar J, de Oliveira Ramos AM, et al. Pathology of congenital Zika syndrome in Brazil: a case series. Lancet. 2016;388(10047):898-904. CrossRef. Medline

54. Besnard M, Eyrolle-Guignot D, Guillemette-Artur P, et al. Congenital cerebral malformations and dysfunction in fetuses and newborns following the 2013 to 2014 Zika virus epidemic in French Polynesia. Euro Surveill. 2016;21(13):30181. CrossRef. Medline

55. de Paula Freitas B, de Oliveira Dias Jr, Prazeres J, et al. Ocular findings in infants with microcephaly associated with presumed Zika virus congenital infection in Salvador, Brazil. JAMA Ophthalmol. 2016;134(5):529-535. CrossRef. Medline

56. Werner H, Sodré D, Hygino C, et al. First-trimester intrauterine Zika virus infection and brain pathology: prenatal and postnatal neuroimaging findings. Prenatal Diagn. 2016;36(8):785-789. CrossRef. Medline 
57. Perez S, Tato R, Cabrera JJ, et al. Confirmed case of Zika virus congenital infection, Spain, March 2016. Euro Surveill. 2016;21(24):30261. CrossRef. Medline

58. Honein MA, Dawson AL, Petersen EE, et al. Birth defects among fetuses and infants of US women with evidence of possible Zika virus infection during pregnancy. JAMA. 2017;317(1):59-68. CrossRef. Medline

59. Costa Carvalho FH, Melo Cordeiro K, Borges Peixoto A, et al. Associated ultrasonographic findings in fetuses with microcephaly because of suspected Zika virus (ZIKV) infection during pregnancy. Prenat Diagn. 2016;36(9):882887. CrossRef. Medline

60. de Barros Miranda-Filho D, Turchi Martelli CM, de Alencar Ximenes RA, et al. Initial description of the presumed congenital Zika syndrome. Am J Public Health. 2016;106(4):598-600. CrossRef. Medline

61. van der Linden V, Pessoa A, Dobyns W, et al. Description of 13 infants born during October 2015-January 2016 with congenital Zika Virus infection without microcephaly at birth - Brazil. MMWR Morb Mortal Wkly Rep. 2016;65(47):1343-1348. CrossRef. Medline

\section{Peer Reviewed}

Competing Interests: None declared

Received: 9 Mar 2018; Accepted: 12 Feb 2019

Cite this article as: Mirambo MM, Matemba L, Majigo M, Mshana SE. Congenital Zika Virus Infection Paradigm: What is in the Wardrobe? A Narrative Review. E Afr Sci. 2019;1(1):49-56. https://doi.org/10.24248/EASci-D-18-00006.

(C) Mirambo et al. This is an open-access article distributed under the terms of the Creative Commons Attribution License, which permits unrestricted use, distribution, and reproduction in any medium, provided the original author and source are properly cited. To view a copy of the license, visit http://creativecommons.org/licens$\mathrm{es} / \mathrm{by} / 4.0 /$. When linking to this article, please use the following permanent link: http://doi.org/10.24248/EASci-D-18-00006. 